\title{
TITLE:
}

\section{Localization of Id2 mRNA in the adult mouse brain(Abstract_要旨 )}

$\operatorname{AUTHOR}(\mathrm{S})$ :

Kitajima, Kazuhito

CITATION:

Kitajima, Kazuhito. Localization of Id2 mRNA in the adult mouse brain. 京都大学, 2006, 博士(医学)

ISSUE DATE:

2006-03-23

URL:

http://hdl.handle.net/2433/143851

RIGHT: 


\begin{tabular}{|c|c|}
\hline 氏 & 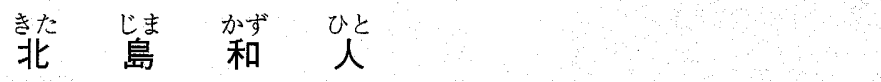 \\
\hline 学位(専攻分野) & 士 (医 学) \\
\hline 学位記 番号 & 医 博 第 2971 号 \\
\hline 学位授与の日付 & 平成 18 年 3 月 23 日 \\
\hline 学位授与の要件 & 学位規則第 4 条第 1 項該当 \\
\hline 研究科・専攻 & 医学研究科脳統御医科学系専攻 \\
\hline 学位論文題目 & $\begin{array}{l}\text { Localization of } \mathrm{Id} 2 \text { mRNA in the adult mouse brain } \\
\text { (分化抑制因子 } \mathrm{Id} 2 \text { mRNA の成体マウス脳内での局在) }\end{array}$ \\
\hline
\end{tabular}

論文調査委員 教授) 影山龍一郎教 授塩田 浩平教 授瀬原淳子

\section{論 文 内 容 の 要 旨}

(目的)

分化抑制因子 Id は basic helix-loop-helix 型転写因子の機能阻害因子であり, 細胞分化と増殖の制御に関与している。 哺乳類では 4 つの Id が単離されており, これらの因子は胎仔期のみならず成体においても, 類似しながらも固有の発現様 式を示す。Id2 はマウス成体脳のプルキンエ細胞や大脳皮質ニューロンで発現していることが知られて㧍り, 細胞分化, 増 殖だけでなく, 成体でも何らかの神経活動に関わっていることが示唆されている。マウス成体の神経系における Id 2 の機能 を考察するために，マウス成体脳での Id2 mRNA の局在を調べた。

(方法)

成体雄 ICR マウス，または NMRI と129/Sv の雑種マウスを $4 \%$ パラホルムアルデヒド/PBS で還流固定後に脳を取り

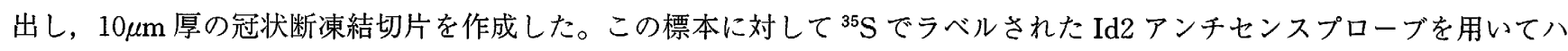
イブリダイゼーションを行った。対比染色にはニッスル染色を用いた。また，Id2 との比較のため Id1，Id3，Id4について も同様にハイブリダイゼーションを行った。さらに，大脳皮質，小脳，線条体から全 RNA を抽出しノザンブロット法によ り各部位のId2 の発現量を評価した。

(結果)

$\mathrm{Id} 2 \mathrm{mRNA}$ は帯状回, 海馬支脚, 扁桃体, 中隔核などの大脳辺縁系, 線条体, 淡蒼球, 黒質網様部などの大脳基底核系, さらに視交叉上核，海馬歯状回，前脳室下領域などでも発現を認め，従来報告されているょりも広範囲に発現していること が示された。視床では，前腹側核，後腹側核に中等度の発現を認めたが，その他の核では発現は少なかった。大脳皮質第 4 層，黒質幑密部などではほとんど発現がなかった。一方，Id1 はほとんど発現を認めず，Id3は脳全体に発現していたが， 歯状回，外包などを除くと発現している細胞はまばらであった。Id4 mRNA は全体に弱い発現であったが，線条体，扁桃 体外側核で比較的強い発現を認めた。いずれも Id2 の分布とは異なっていた。マウス成体脳に扔いて，Id の中では Id2 が 最も強く発現していた。ノザンブロット法による解析では，Id2 は大脳皮質，小脳で強く発現していたが，線条体では発現 が弱かった。

(考察)

Id2 は成体海馬歯状回，前脳室下領域でも発現を認めることから，胎仔期の細胞分化と増殖の制御に関与しているだけで なく，成体の神経幹細胞にも発現し，分化，増殖に関係している可能性がある。また，成体脳に広範囲に発現しており，分 化，増殖だけでなく，中枢神経系の活動にも関わっていると考えられる。大脳皮質，大脳基底核，大脳辺縁系，プルキンエ 細胞，視交叉上核などに分布していることから，運動の調整，認知機能，情動行動，概日リズムなどに関与していることが 示唆された。今後ノックアウトマウスの解析も含め, 更なる研究が必要と考えられる。 
分化抑制因子 Id は basic helix-loop-helix 型転写因子の機能阻害因子であり, 細胞分化と増殖の制御に関与していると 考えられている。哺乳類では 4 つの Id が単離されており，これらの因子は胎仔期のみならず成体においても，類似しなが らも固有の発現様式を示す。マウス成体の神経系に扔けるId2 の機能を考察するために, マウス成体脳でのId2 mRNAの 局在を調べた。 Id 2 mRNA は帯状回, 海馬支脚, 扁桃体, 中隔核などの大脳辺縁系, 線条体, 淡蒼球, 黒質網様部などの 大脳基底核系，視交叉上核，海馬歯状回，前脳室下領域などでも発現を認め，従来の報告よりも広範囲に発現していること が示された。視床では, 前腹側核, 後腹側核に中等度の発現を認めた。一方, Id1 はほとんど発現を認めず, Id 3 は脳全体 に発現していたが，歯状回，外包などを除くと発現している細胞はまばらであった。Id $4 \mathrm{mRNA} は$ 全体に発現は弱いが， 線条体，扁桃体外側核で比較的強い発現を認め，Id2 の分布とは異なっていた。Id2 は成体海馬歯状回，前脳室下領域でも 発現を認めることから，成体の神経幹細胞の維持などに関係している可能性が示唆された。また，成体脳に広範囲に発現し て扔り，分化，増殖だけでなく，成体の中枢神経系の活動にも関与していることが示唆された。

以上の研究は, 分化抑制因子 Id2 の成体マウス脳全部位における局在の解明に貢献し, 中枢神経系の機能の理解に寄与す るところが多い。したがって, 本論文は博士 (医学) の学位論文として価値あるものと認める。なお, 本学位申請者は, 平 成18年 2 月13日実施の論文内容とそれに関連した試問を受け，合格と認められたものである。 